\title{
Synthesis, Characterization, and Antibacterial Studies of Mixed Ligand Dioxouranium Complexes with 8-Hydroxyquinoline and Some Amino Acids
}

\author{
Sunil S. Patil, ${ }^{1}$ Ganesh A. Thakur, ${ }^{2}$ and Manzoor M. Shaikh ${ }^{1}$ \\ ${ }^{1}$ Department of Chemistry, Changu Kana Thakur Arts, Commerce and Science College, New Panvel, Raigad, \\ Maharashtra 410206, India \\ ${ }^{2}$ Department of Chemistry, Mahatma Phule Arts, Science and Commerce College, Panvel, Raigad, \\ Maharashtra 410206, India \\ Correspondence should be addressed to Sunil S. Patil, patil1662@gmail.com \\ Received 9 June 2011; Accepted 1 August 2011 \\ Academic Editors: A. A. Abdel-Aziz, C. Dardonville, S. Demirayak, and C. Safak
}

Copyright ( $) 2011$ Sunil S. Patil et al. This is an open access article distributed under the Creative Commons Attribution License, which permits unrestricted use, distribution, and reproduction in any medium, provided the original work is properly cited.

\begin{abstract}
Mixed ligand complexes of dioxouranium (VI) of the type $\left[\mathrm{UO}_{2}(\mathrm{Q})(\mathrm{L}) \cdot 2 \mathrm{H}_{2} \mathrm{O}\right.$ ] have been synthesized using 8-hydroxyquinoline (HQ) as a primary ligand and amino acids (HL) such as L-threonine, L-tryptophan, and L-isoleucine as secondary ligands. The metal complexes have been characterized by elemental analysis, electrical conductance, magnetic susceptibility measurements, and spectral and thermal studies. The electrical conductance studies of the complexes indicate their nonelectrolytic nature. Magnetic susceptibility measurements revealed diamagnetic nature of the complexes. Electronic absorption spectra of the complexes show intraligand and charge transfer transitions, respectively. Bonding of the metal ion through $\mathrm{N}$ - and O-donor atoms of the ligands is revealed by IR studies, and the chemical environment of the protons is confirmed by NMR studies. The thermal analysis data of the complexes indicate the presence of coordinated water molecules. The agar cup and tube dilution methods have been used to study the antibacterial activity of the complexes against the pathogenic bacteria S. aureus, C. diphtheriae, S. typhi, and E. coli.
\end{abstract}

\section{Introduction}

It is well known that mixed ligand ternary complexes of some metals play an important role in the activation of enzymes [1]. It is studied that mixed ligand complexes are biologically active against pathogenic microorganisms [2, 3]; further, metal complexes, which include 8-hydroxyquinoline as a primary ligand, exhibit biological activity [4]. Ternary complexes containing an amino acid as a secondary ligand have a significance as they are potential models for enzyme metal ion substrate complexes [5]. Numerous uranium complexes and their mixed chelates have been studied [6, 7]. A large number of complexes with varying geometries of dioxoura$\operatorname{nium}(\mathrm{VI}), \mathrm{UO}_{2}{ }^{2+}$ oxocations are possible [8]. The coordination numbers ranging from 7 to 12 for metal chelates of $\mathrm{UO}_{2}(\mathrm{VI})$ and $\mathrm{Th}(\mathrm{IV})$ have been reported $[9,10]$. Recently, it was stated that the $\mathrm{UO}_{2}(\mathrm{VI})$ complexes show antimicrobial activity $[11,12]$.
This paper reports the synthesis, characterization, and antibacterial studies of mixed ligand dioxouranium(VI) complexes prepared with 8-hydroxyquinoline as a primary ligand and amino acids such as L-threonine, L-tryptophan, and L-isoleucine as secondary ligands. These complexes have been screened for their antibacterial properties against the pathogenic bacteria S. aureus, C. diphtheriae, S. typhi, and E. coli.

\section{Materials and Methods}

2.1. Materials. Analytical grade uranyl nitrate hexahydrate was used as such without further purification. L-threonine, L-tryptophan, L-isoleucine, and 8-hydroxyquinoline were obtained from S.D. Fine Chemicals, Mumbai. Solvents like ethanol and dimethylformamide and laboratory grade chemicals whenever used were distilled and purified according to standard procedures $[13,14]$. 
2.2. Preparation of Mixed Ligand Complexes. Mixed ligand dioxouranium(VI) complexes were prepared from uranyl nitrate hexahydrate, 8-hydroxyquinoline (HQ) as a primary ligand, and different amino acids such as L-threonine, Ltryptophan, and L-isoleucine as secondary ligands.

To an aqueous solution $(10 \mathrm{~mL})$ of uranyl nitrate hexahydrate $(502 \mathrm{mg}, 1 \mathrm{mmol})$, ethanolic solution $(10 \mathrm{~mL})$ of 8 hydroxyquinoline $(145 \mathrm{mg}, 1 \mathrm{mmol})$ was added. The mixture was stirred and kept in a boiling water bath for $10 \mathrm{~min}$. To this hot solution, an aqueous solution $(10 \mathrm{~mL})$ of amino acid ( $1 \mathrm{mmol}$ ) was added with constant stirring. The mixture (1:1:1 molar proportion) was again heated in a water bath for $10 \mathrm{~min}$ till the temperature reached to $50^{\circ} \mathrm{C}$. The complexes were precipitated by raising the $\mathrm{pH}$ of the reaction mixture by adding diluted ammonia solution. The mixture was cooled, and solid complex obtained was filtered and washed with water followed by ethanol. The complexes thus prepared were dried under vacuum and were used for further studies.

2.3. Instrumentation. The complexes were analyzed for $\mathrm{C}, \mathrm{H}$, and $\mathrm{N}$ contents on Thermo Finnigan Elemental Analyzer Model no. FLASH EA 1112 Series at the Department of Chemistry, I.I.T., Mumbai. Metal content was estimated gravimetrically by standard procedure [15]. The molar conductance values were measured in DMF $\left(10^{-3} \mathrm{M}\right)$ on an Equiptronics Autoranging Conductivity Meter Model No. EQ-667. Room temperature magnetic susceptibilities were measured by a Guoy method using $\mathrm{Hg}\left[\mathrm{Co}(\mathrm{SCN})_{4}\right]$ as a calibrant at the Department of Chemistry, I.I.T., Mumbai. The electronic absorption spectra of all the complexes in DMF solution $\left(10^{-4} \mathrm{M}\right)$ in the ultraviolet and visible region were recorded on Shimadzu UV/VIS-160 Spectrophotometer. FTIR spectra were recorded in $\mathrm{KBr}$ disc on a Perkin-Elmer FTIR spectrophotometer Model 1600 at Department of Chemistry, I.I.T., Mumbai. NMR spectra were recorded on JEOL$300 \mathrm{MHz}$ instrument using TMS as an internal standard at The Institute of Science, Mumbai. Thermal Analysis (TG and DTA) were carried out in controlled nitrogen atmosphere on a Perkin-Elmer Diamond TG-DTA Instrument at Department of Chemistry, I.I.T., Mumbai by recording the change in weight of the complexes on increasing temperature up to $900^{\circ} \mathrm{C}$ at the heating rate of $10^{\circ} \mathrm{C}$ per minute.

\subsection{Antibacterial Screening}

2.4.1. Agar Cup Method. In the agar cup method, a single compound can be tested against a number of organisms or a given organism against different concentrations of the same compound. The method was found suitable for semisolid or liquid samples and was used in the present work. In the agar cup method, a plate of sterile nutrient agar with the desired test strain was poured to a height of about $5 \mathrm{~mm}$ and allowed to solidify, and a single cup of about $8 \mathrm{~mm}$ diameter was cut from the center of the plate with a sterile cork borer. Thereafter, the cup was filled with the sample solution $(1000 \mu \mathrm{g} / \mathrm{mL})$ in dimethylsulphoxide, and the plate was incubated at $37^{\circ} \mathrm{C}$ for $24 \mathrm{~h}$. The extent of inhibition of growth from the edge of the cup was considered as a measure of the activity of the given compound. By using several plates simultaneously, the activities of several samples were quantitatively studied.

2.4.2. Tube Dilution Method. The test compound (10 mg) was dissolved in dimethylsulphoxide $(10 \mathrm{~mL})$ so as to prepare a stock solution of concentration $1000 \mu \mathrm{g} / \mathrm{mL}$. From this stock solution, aliquots of the ranges $5,10,15, \ldots, 250 \mu \mathrm{g} / \mathrm{mL}$ were obtained in test broth.

The test compounds were subjected to in vitro screening against Staphylococcus aureus, Corynebacterium diphtheriae, Salmonella typhi, and Escherichia coli using Muller Hinton broth as the culture medium.

Bacterial inoculums were prepared in sterilized Mueller Hinton broth and incubated for $4 \mathrm{~h}$ at $37^{\circ} \mathrm{C}$. This was dispersed $(5 \mathrm{~mL})$ in each borosilicate test tube $(150 \times 20 \mathrm{~mm})$. The test sample solution was added in order to attain a final concentration as 5 to $250 \mu \mathrm{g} / \mathrm{mL}$. The bacterial inoculums $0.1 \mathrm{~cm}^{3}$ of the desired bacterial strain (S. aureus, C. diphtheriae, S. typhi, and E. coli) containing $10^{6}$ bacteria/mL was inoculated in the tube. The tubes were incubated at $37^{\circ} \mathrm{C}$ for $24 \mathrm{~h}$ and then examined for the presence or absence of the growth of the test organisms.

The lowest concentration which showed no visible growth was noted as minimum inhibitory concentration (MIC).

\section{Results and Discussion}

3.1. Characterization of Metal Complexes. The synthesis of mixed ligand uranyl complexes may be represented as follows:

$$
\begin{aligned}
& \mathrm{UO}_{2}\left(\mathrm{NO}_{3}\right)_{2} \cdot 6 \mathrm{H}_{2} \mathrm{O}+\mathrm{HQ}+\mathrm{HL} \\
& \quad \longrightarrow\left[\mathrm{UO}_{2}(\mathrm{Q})(\mathrm{L}) \cdot 2 \mathrm{H}_{2} \mathrm{O}\right]+2 \mathrm{HNO}_{3}+4 \mathrm{H}_{2} \mathrm{O}
\end{aligned}
$$

(where HQ is 8-hydroxyquinoline and HL is an amino acid).

All the complexes are coloured, nonhygroscopic, thermally stable solids (Table 1), indicating a strong metal-ligand bond. The complexes are insoluble in common organic solvents such as ethyl alcohol, acetone, and chloroform but are partially soluble in DMF and DMSO.

The elemental analysis data (Table 2) of uranyl complexes are consistent with their general formulation as $1: 1: 1$, mixed ligand of the type $\left[\mathrm{UO}_{2}(\mathrm{Q})(\mathrm{L}) \cdot 2 \mathrm{H}_{2} \mathrm{O}\right]$. The molar conductance values (Table 2) of the complexes in DMF at $10^{-3} \mathrm{M}$ concentration are found to be $0.001-0.002$ Mhos $\mathrm{cm}^{2}$ $\mathrm{mol}^{-1}$ indicating their nonelectrolytic nature [16].

3.2. Magnetic Studies. The magnetic moment (Table 3) of the complexes was calculated from the measured magnetic susceptibilities after employing diamagnetic corrections and revealed their diamagnetic nature [17]. 
TABLE 1: Colour, decomposition temperature, and $\mathrm{pH}$ of the uranyl complexes.

\begin{tabular}{lcccc}
\hline Sr. no. & Complex & Colour & Decomposition temperature $\left({ }^{\circ} \mathrm{C}\right)$ & $\mathrm{pH}$ \\
\hline$(1)$ & {$\left[\mathrm{UO}_{2}(\mathrm{Q})(\mathrm{Thr}) \cdot 2 \mathrm{H}_{2} \mathrm{O}\right]$} & Light Brown & 265 & 7.00 \\
$(2)$ & {$\left[\mathrm{UO}_{2}(\mathrm{Q})(\right.$ Try $\left.) \cdot 2 \mathrm{H}_{2} \mathrm{O}\right]$} & Light Brown & 257 & 7.00 \\
$(3)$ & {$\left[\mathrm{UO}_{2}(\mathrm{Q})(\mathrm{Iso}) \cdot 2 \mathrm{H}_{2} \mathrm{O}\right]$} & Light Brown & 250 & 7.00 \\
\hline
\end{tabular}

Where $\mathrm{Q}$ represents the deprotonated primary ligand 8-hydroxyquinoline, Thr, Try, and Iso represent deprotonated secondary ligands L-threonine, L-tryptophan, and L-isoleucine, respectively.

TABle 2: Empirical Formula, Molecular Weight, Elemental Analysis Data and Molar Conductance of Uranyl Complexes.

\begin{tabular}{|c|c|c|c|c|c|c|c|c|}
\hline \multirow{2}{*}{ Sr. no. } & \multirow{2}{*}{ Complex } & \multirow{2}{*}{$\begin{array}{l}\text { Empirical } \\
\text { formula }\end{array}$} & \multirow{2}{*}{$\begin{array}{c}\text { Molecular } \\
\text { weight }\end{array}$} & \multicolumn{4}{|c|}{ Elemental analysis Found (Calculated) } & \multirow{2}{*}{$\begin{array}{l}\text { Molar conductance } \\
\text { Mhos } \cdot \mathrm{cm}^{2} \mathrm{moL}^{-1}\end{array}$} \\
\hline & & & & $\% \mathrm{M}$ & $\% \mathrm{C}$ & $\% \mathrm{H}$ & $\% \mathrm{~N}$ & \\
\hline (1) & {$\left[\mathrm{UO}_{2}(\mathrm{Q})(\mathrm{Thr}) \cdot 2 \mathrm{H}_{2} \mathrm{O}\right]$} & $\mathrm{UC}_{13} \mathrm{H}_{18} \mathrm{~N}_{2} \mathrm{O}_{8}$ & 568.31 & $\begin{array}{c}41.81 \\
(41.88)\end{array}$ & $\begin{array}{c}27.40 \\
(27.45)\end{array}$ & $\begin{array}{c}3.15 \\
(3.17)\end{array}$ & $\begin{array}{c}4.91 \\
(4.93)\end{array}$ & 0.001 \\
\hline (2) & {$\left[\mathrm{UO}_{2}(\mathrm{Q})(\operatorname{Try}) \cdot 2 \mathrm{H}_{2} \mathrm{O}\right]$} & $\mathrm{UC}_{20} \mathrm{H}_{21} \mathrm{~N}_{3} \mathrm{O}_{7}$ & 653.42 & $\begin{array}{c}36.43 \\
(36.43)\end{array}$ & $\begin{array}{c}36.72 \\
(36.73)\end{array}$ & $\begin{array}{c}3.20 \\
(3.21)\end{array}$ & $\begin{array}{c}6.41 \\
(6.43)\end{array}$ & 0.001 \\
\hline (3) & {$\left[\mathrm{UO}_{2}(\mathrm{Q})(\mathrm{Iso}) \cdot 2 \mathrm{H}_{2} \mathrm{O}\right]$} & $\mathrm{UC}_{15} \mathrm{H}_{22} \mathrm{~N}_{2} \mathrm{O}_{7}$ & 580.37 & $\begin{array}{c}41.00 \\
(41.01) \\
\end{array}$ & $\begin{array}{c}31.01 \\
(31.01) \\
\end{array}$ & $\begin{array}{c}3.76 \\
(3.79) \\
\end{array}$ & $\begin{array}{c}4.81 \\
(4.82) \\
\end{array}$ & 0.002 \\
\hline
\end{tabular}

TABLE 3: Magnetic susceptibility data of uranyl complexes $\left(-10^{-6}\right.$ c.g.s. units).

\begin{tabular}{lcccc}
\hline Sr. no. & Complex & $X_{g}$ & $X_{m}$ & $\mu_{\text {eff }}$ B.M. \\
\hline$(1)$ & {$\left[\mathrm{UO}_{2}(\mathrm{Q})(\mathrm{Thr}) \cdot 2 \mathrm{H}_{2} \mathrm{O}\right]$} & 0.6844 & 389.00 & Diamagnetic \\
$(2)$ & {$\left[\mathrm{UO}_{2}(\mathrm{Q})(\mathrm{Try}) \cdot 2 \mathrm{H}_{2} \mathrm{O}\right]$} & 0.9499 & 620.69 & Diamagnetic \\
$(3)$ & {$\left[\mathrm{UO}_{2}(\mathrm{Q})(\mathrm{Iso}) \cdot 2 \mathrm{H}_{2} \mathrm{O}\right]$} & 0.9855 & 571.99 & Diamagnetic \\
\hline
\end{tabular}

3.3. Electronic Absorption Spectra. The electronic spectra of the metal complexes in DMF were recorded in the UVvisible region. The spectra show three transitions in the range $36364-36765 \mathrm{~cm}^{-1}, 29762-30303 \mathrm{~cm}^{-1}$, and $25253-$ $26316 \mathrm{~cm}^{-1}$ ascribed to $\pi \rightarrow \pi^{*}, n \rightarrow \pi^{*}$, and the charge transfer transitions from the ligands to the metal, respectively.

3.4. Infrared Spectra. The FT-IR spectra of the metal complexes were recorded for $\mathrm{KBr}$ discs over the range 4000$400 \mathrm{~cm}^{-1}$. On the basis of the reported infrared spectra of amino acids, 8-hydroxyquinoline, and its metal complexes [18-20], some of the important bands have been assigned.

A broad band was observed in the region between 3460 and $3431 \mathrm{~cm}^{-1}$ due to asymmetric and symmetric $\mathrm{O}-\mathrm{H}$ stretching modes and a band in the range $1600-1585 \mathrm{~cm}^{-1}$ due to $\mathrm{H}-\mathrm{O}-\mathrm{H}$ bending vibrations indicating the presence of coordinated water molecules further confirmed by thermal studies.

The $v(\mathrm{CO})$ band is observed at $\sim 1120 \mathrm{~cm}^{-1}$. The position of this band undergoes variation depending on metal complex under study [21]. A strong $v(\mathrm{CO})$ band observed in the range between 1106 and $1105 \mathrm{~cm}^{-1}$ indicates the presence of oxine moiety in the complexes coordinated through its nitrogen and oxygen atoms as uninegative bidentate ligand [22]. The $v(\mathrm{C}=\mathrm{N})$ mode observed at $1580 \mathrm{~cm}^{-1}$ in the spectra of free HQ ligand is found to be shifted to lower wave number, in the range of $1498-1497 \mathrm{~cm}^{-1}$ in the spectra of complexes. A negative shift in this vibrational mode on complexation indicates the coordination through ternary nitrogen donor of HQ. The in-plane and out-of-plane ring deformation modes observed at $506 \mathrm{~cm}^{-1}$ and $786 \mathrm{~cm}^{-1}$ respectively, confirm coordination through nitrogen atom of HQ with the metal.

Broad bands at 3040 and $2960 \mathrm{~cm}^{-1}$ due to N-H (asymmetric) and $\mathrm{N}-\mathrm{H}$ (symmetric) vibrations of free amino acid moiety are shifted to higher wave numbers, in the range $3177-3140 \mathrm{~cm}^{-1}$ and $3050-3025 \mathrm{~cm}^{-1}$, respectively, in the spectra of metal complexes, suggesting coordination of the amino group through nitrogen with the metal ion.

The $v_{\text {asymmetric }}\left(\mathrm{COO}^{-}\right)$band of the free amino acid, that is, $1610-1590 \mathrm{~cm}^{-1}$, is shifted to lower wave number, in the range of $1571-1566 \mathrm{~cm}^{-1}$, and the $v_{\text {symmetric }}\left(\mathrm{COO}^{-}\right)$mode observed at $\sim 1400 \mathrm{~cm}^{-1}$ in the spectra of free amino acids is found to be shifted to lower wave number $1378 \mathrm{~cm}^{-1}$, in the spectra of complexes indicating the coordination of the carboxylic acid group via oxygen with the metal ion [18].

An important feature of infrared spectra of the metal complexes with 8 -HQ is the absence of band $\sim 3440 \mathrm{~cm}^{-1}$ due to the $\mathrm{O}-\mathrm{H}$ stretching vibration of the free $\mathrm{O}-\mathrm{H}$ group of HQ [20]. This observation leads to the conclusion that complex formation takes place by deprotonation of the hydroxyl group of HQ moiety.

The FT-IR spectra of the uranyl complexes show no absorption bands near $1352 \mathrm{~cm}^{-1}$ where ionic nitrate is known to absorb [23], indicating absence of ionic nitrate. Other bands observed at $\sim 1468, \sim 1278, \sim 1035$, and $\sim 734 \mathrm{~cm}^{-1}$ corresponding to $v_{1}, v_{4}, v_{2}$, and $v_{3}$ vibrations agree with frequencies reported for bidentate nitrate group [24, 25]. 
TABLE 4: Thermal data of uranyl complexes.

\begin{tabular}{|c|c|c|c|c|c|c|}
\hline \multirow{2}{*}{ Sr. no. } & \multirow{2}{*}{ Complex } & \multirow{2}{*}{ Decomposition temperature $\left({ }^{\circ} \mathrm{C}\right)$} & \multirow{2}{*}{ Temperature range $\left({ }^{\circ} \mathrm{C}\right)$} & \multicolumn{2}{|c|}{$\%$ Weight loss } & \multirow{2}{*}{ Decomposition product } \\
\hline & & & & Found & Calculated & \\
\hline \multirow{3}{*}{ (1) } & \multirow{3}{*}[\mathrm{UO}_{2}(\mathrm{Q})(\mathrm{Thr})\cdot2\mathrm{H}_{2}\mathrm{O}]{} & \multirow{3}{*}{250} & $110-190$ & 06.00 & 06.04 & {$\left[\mathrm{UO}_{2}(\mathrm{Q})(\mathrm{Lys})\right]$} \\
\hline & & & $250-360$ & 24.20 & 24.35 & {$\left[\mathrm{UO}_{2}(\mathrm{Q})\right]$} \\
\hline & & & $425-550$ & 24.10 & 24.19 & {$\left[\mathrm{UO}_{2}\right]$} \\
\hline \multirow{3}{*}{ (2) } & \multirow{3}{*}[\mathrm{UO}_{2}(\mathrm{Q})(\mathrm{Try})\cdot2\mathrm{H}_{2}\mathrm{O}]{} & \multirow{3}{*}{260} & $110-190$ & 06.00 & 06.18 & {$\left[\mathrm{UO}_{2}(\mathrm{Q})(\right.$ Asp $\left.)\right]$} \\
\hline & & & $260-360$ & 22.52 & 22.67 & {$\left[\mathrm{UO}_{2}(\mathrm{Q})\right]$} \\
\hline & & & $430-520$ & 24.51 & 24.73 & {$\left[\mathrm{UO}_{2}\right]$} \\
\hline \multirow{3}{*}{ (3) } & \multirow{3}{*}[\mathrm{UO}_{2}(\mathrm{Q})(\mathrm{Iso})\cdot2\mathrm{H}_{2}\mathrm{O}]{} & \multirow{3}{*}{230} & $110-160$ & 06.31 & 06.31 & {$\left[\mathrm{UO}_{2}(\mathrm{Q})(\mathrm{Cys})\right]$} \\
\hline & & & $230-380$ & 21.02 & 21.04 & {$\left[\mathrm{UO}_{2}(\mathrm{Q})\right]$} \\
\hline & & & $460-585$ & 25.00 & 25.25 & {$\left[\mathrm{UO}_{2}\right]$} \\
\hline
\end{tabular}

TABLE 5: Antibacterial activity ( $\mathrm{mm}$ ) of uranyl complexes by agar cup method.

\begin{tabular}{lcccc}
\hline Sr. no. & Complex & \multicolumn{2}{c}{ Test } & S. typhi \\
\hline$(1)$ & {$\left[\mathrm{UO}_{2}(\mathrm{Q})(\mathrm{Thr}) \cdot 2 \mathrm{H}_{2} \mathrm{O}\right]$} & S. aureus & C. diphtheriae & 20 \\
$(2)$ & {$\left[\mathrm{UO}_{2}(\mathrm{Q})(\mathrm{Try}) \cdot 2 \mathrm{H}_{2} \mathrm{O}\right]$} & 12 & 12 & 26 \\
$(3)$ & {$\left[\mathrm{UO}_{2}(\mathrm{Q})(\mathrm{Iso}) \cdot 2 \mathrm{H}_{2} \mathrm{O}\right]$} & 13 & 12 & 26 \\
$(4)$ & Tetracycline & 30 & 25 & 26 \\
\hline
\end{tabular}

The bands at $898-889 \mathrm{~cm}^{-1}$ and $821-820 \mathrm{~cm}^{-1}$ were assigned to $v_{\text {asymmetric }}(\mathrm{O}-\mathrm{U}-\mathrm{O})$ and $v_{\text {symmetric }}(\mathrm{O}-\mathrm{U}-\mathrm{O})$ vibrational modes of linear $\mathrm{O}=\mathrm{U}=\mathrm{O}$ moiety $[26,27]$.

Some new bands of weak intensity observed in the regions around $604 \mathrm{~cm}^{-1}$ and $486 \mathrm{~cm}^{-1}$ may be ascribed to the $\mathrm{M}-\mathrm{O}$ and $\mathrm{M}-\mathrm{N}$ vibrations, respectively [28]. It may be noted that these vibrational bands are absent in the infrared spectra of HQ as well as amino acids.

3.5. NMR Spectra. ${ }^{1} \mathrm{H}$ NMR spectra of complexes in DMSO exhibits a singlet at $\delta 2.8 \mathrm{ppm}\left(2 \mathrm{H} ;-\mathrm{NH}_{2}\right)$ due to amino group protons and broad multiplet in the region $\delta 6.6-$ $7.8 \mathrm{ppm}(6 \mathrm{H}$; aromatic protons) due to the aromatic ring protons. The presence of water molecules in the complexes is confirmed by the appearance of a new signal around $\delta$ $3.5 \mathrm{ppm}$, attributed to $\mathrm{H}_{2} \mathrm{O}$ protons [29].

In case of complex with L-threonine it shows doublet at d $1.26 \mathrm{ppm}(J=7.5 \mathrm{~Hz})$ for three protons of methyl group, doublet at $\delta 2.52 \mathrm{ppm}(J=7.5 \mathrm{~Hz})$ for one proton of $-\mathrm{CH}$, multiplet at $\delta 2.90-2.96 \mathrm{ppm}\left(-\mathrm{CH}-\mathrm{CH}_{3}\right)$ for one proton of $-\mathrm{CH}$, and singlet at $\delta 10.1 \mathrm{ppm}$ for hydroxyl proton which was $\mathrm{D}_{2} \mathrm{O}$ exchangeable.

The complex with L-tryptophan shows doublet at $\delta$ $2.76 \mathrm{ppm}(J=8.0 \mathrm{~Hz})$ for two protons of methylene group, triplet at $\delta 2.94 \mathrm{ppm}(J=8.0 \mathrm{~Hz})$ for one proton of $-\mathrm{CH}$, singlet at $\delta 5.25 \mathrm{ppm}$ for one proton of $-\mathrm{NH}$ which was $\mathrm{D}_{2} \mathrm{O}$ exchangeable, and multiplet at $\delta 6.6-7.2 \mathrm{ppm}$ (indole ring protons for aromatic protons.

The complex with L-isoleucine shows triplet at $\delta$ $0.93 \mathrm{ppm}(\mathrm{J}=7.0 \mathrm{~Hz})\left(-\mathrm{CH}_{2}-\mathrm{CH}_{3}\right)$ for three protons of methyl group, doublet at $\delta 1.15 \mathrm{ppm}(J=7.0 \mathrm{~Hz})(-\mathrm{CH}-$ $\mathrm{CH}_{3}$ ) for three protons of another methyl group, multiplet at $\delta 1.50-1.57 \mathrm{ppm}$ for two protons of $-\mathrm{CH}_{2}$, another multiplet at $\delta 1.60-1.68 \mathrm{ppm}$ for one proton of $-\mathrm{CH}$, and doublet at $\delta$ $2.92 \mathrm{ppm}(J=7.0 \mathrm{~Hz})$ for one proton of another $-\mathrm{CH}$.

3.6. Thermal Studies. The TG and DTA studies of the uranyl complexes have been recorded in the nitrogen atmosphere at the constant heating rate of $10^{\circ} \mathrm{C}$ per minute.

The TG of the uranyl complexes shows that they are thermally quite stable to varying degree. The complexes show gradual loss in weight due to decomposition by fragmentation with increasing temperature as presented in Table 4. All the complexes show similar behavior in TG and DTA studies. The thermogram of these complexes shows the loss in weight corresponding to two water molecules in the temperature range $110-190^{\circ} \mathrm{C}$, followed by weight loss due to amino acid moiety in the range $250-445^{\circ} \mathrm{C}$. The final step of the decomposition observed in the range $450-690^{\circ} \mathrm{C}$ corresponds to the weight loss of HQ moiety present in the complexes.

The DTA of the complexes displays an endothermic peak in the range $110-190^{\circ} \mathrm{C}$ which indicates the presence of coordinated water molecules. As the temperature is raised, the DTA curve shows a small exotherm in the range $250-445^{\circ} \mathrm{C}$ and a broad exotherm in the range $450-690^{\circ} \mathrm{C}$ attributed to decomposition of amino acid and 8-hydroxyquinoline moieties present in the complexes, respectively. The formation of a broad exotherm is possibly due to simultaneous decomposition of ligand moieties and their subsequent oxidation to gaseous products like $\mathrm{CO}_{2}$ and $\mathrm{H}_{2} \mathrm{O}$ and so forth [17].

Like most of the metal organic complexes, these complexes also decompose to a fine powder of metal oxide, that is, $\mathrm{UO}_{2}$. The constant weight plateau in TG after $700^{\circ} \mathrm{C}$ indicates completion of the reaction. The $\mathrm{UO}_{2}$ form was confirmed by X-ray diffraction pattern of the decomposed product [17]. 
TABLE 6: MIC data of uranyl complexes.

\begin{tabular}{|c|c|c|c|c|c|}
\hline \multirow{2}{*}{ Sr. no. } & \multirow{2}{*}{ Complex } & \multicolumn{4}{|c|}{$\operatorname{MIC}(\mu \mathrm{g} / \mathrm{mL})$} \\
\hline & & S. aureus & C. diphtheriae & S. typhi & E. coli \\
\hline (1) & {$\left[\mathrm{UO}_{2}(\mathrm{Q})(\mathrm{Thr}) \cdot 2 \mathrm{H}_{2} \mathrm{O}\right]$} & 20 & 20 & 5 & 10 \\
\hline (2) & {$\left[\mathrm{UO}_{2}(\mathrm{Q})(\operatorname{Try}) \cdot 2 \mathrm{H}_{2} \mathrm{O}\right]$} & 20 & 25 & 10 & 10 \\
\hline (3) & {$\left[\mathrm{UO}_{2}(\mathrm{Q})(\mathrm{Iso}) \cdot 2 \mathrm{H}_{2} \mathrm{O}\right]$} & 20 & 20 & 10 & 5 \\
\hline$(4)$ & $\mathrm{UO}_{2}\left(\mathrm{NO}_{3}\right)_{2} \cdot 6 \mathrm{H}_{2} \mathrm{O}$ & 50 & 50 & 100 & 100 \\
\hline$(5)$ & 8-hydroxyquinoline & 50 & 50 & 110 & 100 \\
\hline$(6)$ & Tetracycline & 1.5 & 2.0 & 1.5 & 2.5 \\
\hline
\end{tabular}

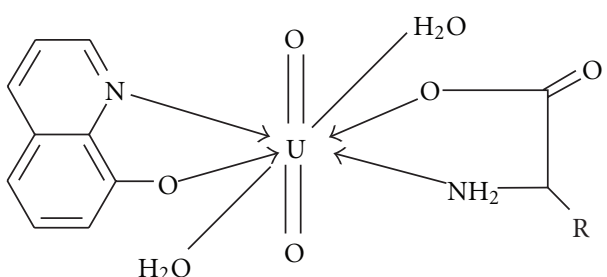

$\mathrm{R}=-\frac{\mathrm{H}}{\mathrm{C}}-\mathrm{CH}_{3}$

(Thr)
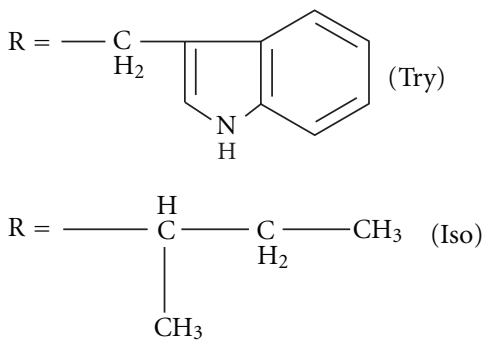

Figure 1: Proposed structures and bonding for the uranyl complexes.

On the basis of the physicochemical studies, the bonding and structure for the uranyl complexes may be represented as shown in Figure 1.

3.7. Antibacterial Studies. All the metal complexes were screened against Staphylococcus aureus, Corynebacterium diphtheriae, Salmonella typhi, and Escherichia coli.

The studies based on agar cup method revealed that the complexes are more active against $S$. typhi and E. coli and less active against $S$. aureus and $C$. diphtheria (Table 5).

The minimum inhibitory concentration (MIC) of ligand and the metal salts ranges between 50 and $110 \mu \mathrm{g} / \mathrm{mL}$ while that of metal complexes ranges between 5 and $25 \mu \mathrm{g} / \mathrm{mL}$ (Table 6). The complexes are found to be more active against S. typhi and E. coli as compared to S. aureus and C. diphtheria. As compared to standard antibacterial compound tetracycline, the complexes show moderate activity against selected strains of microorganisms [30].
The results show that, as compared to the activity of metal salts and free ligand, the metal complexes show higher activity. The activity of metal complexes is enhanced due to chelation. The chelation reduces considerably the polarity of the metal ions in the complexes, which in turn increases the hydrophobic character of the chelate and thus enables its permeation through the lipid layer of microorganisms [31].

\section{Conclusions}

Based on the above results, the following conclusions may be drown.

The higher decomposition temperatures of the complexes indicate a strong metal-ligand bond, and electrical conductance studies show nonelectrolytic nature of the complexes, respectively. Magnetic studies indicate diamagnetic nature of the complexes. Electronic absorption spectra of the complexes show intraligand and charge transfer transitions, respectively. IR spectra show bonding of the metal ion through $\mathrm{N}$ - and $\mathrm{O}$ - donor atoms of the two ligands. ${ }^{1} \mathrm{H} \mathrm{NMR}$ study reveals the chemical environment of protons and presence of water molecules in the complexes. Thermal analysis confirms the presence of coordinated water molecules.

On the basis of the above results, coordination number eight is proposed for uranyl complexes.

The antibacterial study shows that complexes are found to be more active against S. typhi and E. coli as compared to $S$. aureus and $C$. diphtheria.

Compared to standard antibacterial compound, tetracycline, the complexes show moderate activity against the selected strains of microorganisms.

\section{Acknowledgment}

The authors are grateful to Dr. S. T. Gadade, a Principal in Changu Kana Thakur Arts, Commerce and Science College, New Panvel and a Member of the Management Council, University of Mumbai for providing the laboratory and library facilities.

\section{References}

[1] M. N. Hughes, "Coordination compounds in biology," in Comprehensive Coordination Chemistry, G. Wilkinson, R. D. Gillard, and J. A. McCleverty, Eds., vol. 6, p. 541, Pergamon Press, Oxford, UK, 1987. 
[2] J. R. Thakkar and N. V. Thakkar, "Synthesis and characterization of chiral mixed ligand $\mathrm{Co}$ (II) complexes of isonitrosopropiophenone and amino acids," Synthesis and Reactivity in Inorganic and Metal-Organic Chemistry, vol. 30, no. 10, pp. 1871-1887, 2000.

[3] V. S. Shivankar and N. V. Thakkar, "Synthesis, characterization and antimicrobial activity of some mixed ligandCo(II) and Ni(II) complexes," Acta Poloniae Pharmaceutica, vol. 60, no. 1, pp. 45-50, 2003.

[4] H. E. Howard-Lock and C. J. L. Lock, "Uses in therapy," in Comprehensive Coordination Chemistry, G. Wilkinson, R. D. Gillard, and J. A. McCleverty, Eds., vol. 6, p. 755, Pergamon Press, Oxford, UK, 1987.

[5] H. C. Freeman, "Metal complexes of amino acids and peptides," in Inorganic Biochemistry, G. L. Eichhorn, Ed., vol. 1, p. 121, Elsevier, Amsterdam, The Netherlands, 1973.

[6] P. C. Kundu, P. S. Roy, and R. K. Banerjee, "Studies on the different forms of some mixed chelate complexes of dioxouranium(VI) with cupferron," Journal of Inorganic and Nuclear Chemistry, vol. 42, no. 6, pp. 851-862, 1980.

[7] A. Anderson, C. Chieh, D. E. Irish, and J. P. Tony, "An Xray crystallographic, Raman, and infrared spectral study of crystalline potassium uranyl carbonate, K4UO2(CO3)3," Canadian Journal of Chemistry, vol. 58, no. 16, pp. 1651-1658, 1980.

[8] K. W. Bagnall, "The actinides," in Comprehensive Coordination Chemistry, G. Wilkinson, R. D. Gillard, and J. A. McCleverty, Eds., vol. 3, p. 1129, Pergamon Press, Oxford, UK, 1987.

[9] S. A. Abdel-Latif, "Synthesis and characterization of some 3Phenyl-4-arylazo-5-pyrazolones with La(III), Ce(III), Th(IV), and $\mathrm{UO}_{2}(\mathrm{VI})$ Complexes," Synthesis and Reactivity in Inorganic and Metal-Organic Chemistry, vol. 31, p. 1355, 2001.

[10] A. D. Keramidas, M. P. Rikkou, C. Drouza, C. P. Raptopoulou, A. Terzis, and I. Pashalidis, "Investigation on uranyl interaction with bioactive ligands. Synthesis and structural studies of the uranyl complexes with glycine and $\mathrm{N}$-(2-mercaptopropionyl)glycine," Radiochimica Acta, vol. 90, no. 9-11, pp. 549554, 2002.

[11] M. E. Moustafa, "Synthesis and structural and biological activity studies on some lanthanide chelates with $\mathrm{O}$ - and N-containing ligands," Spectroscopy Letters, vol. 38, no. 1, pp. 23-34, 2005.

[12] M. M. Mashaly, T. M. Ismail, S. B. El-Maraghy, and H. A. Habib, "Heteronuclear complexes of oxorhenium(V) with $\mathrm{Fe}(\mathrm{III}), \mathrm{Co}(\mathrm{II}), \mathrm{Ni}(\mathrm{II}), \mathrm{Cu}(\mathrm{II}), \mathrm{Cd}(\mathrm{II})$ and UO2(VI) and their biological activities," Journal of Coordination Chemistry, vol. 57, no. 13, pp. 1099-1123, 2004.

[13] D. D. Perrin, D. R. Perrin, and W. L. F. Armarego, Purification of Laboratory Chemicals, Pergamon Press, Elmsford, NY, USA, 2nd edition, 1980.

[14] A. I. Vogel, Textbook of Practical Organic Chemistry, Longmans Green and Co., London, UK, 5th edition, 1989.

[15] A. I. Vogel, Quantitative Inorganic Analysis, ELBS, London, UK, 4th edition, 1965.

[16] W. J. Geary, "The use of conductivity measurements in organic solvents for the characterisation of coordination compounds," Coordination Chemistry Reviews, vol. 7, no. 1, pp. 81-122, 1971.

[17] G. A. Thakur and M. M. Shaikh, "Synthesis, characterization, antibacterial and cytotoxicity studies on some mixed ligand Th(IV) complexes," Acta Poloniae Pharmaceutica, vol. 63, no. 2, pp. 95-100, 2006.

[18] M. S. Islam, M. S. Ahmed, S. C. Pal, Y. Reza, and S. Jesmine, "Synthesis and characterization of platinum(IV) and gold(III) complexes of amino acids and 8-hydroxyquinoline.," Indian Journal of Chemistry A, vol. 34, p. 816, 1995.

[19] V. Bhagwat, V. Sharma, and N. S. Poonia, "Complexes of $\mathrm{Cr}$ (III) with glycine, alanine, valine and leucine," Indian Journal of Chemistry A, vol. 15, p. 46, 1977.

[20] K. Nakamoto, V. Morimoto, and A. E. Martell, "Infrared spectra of aqueous solutions. I. Metal chelate compounds of amino acids," Journal of the American Chemical Society, vol. 83, no. 22, pp. 4528-4532, 1961.

[21] R. C. Charles, H. Freiser, R. Friedel, L. E. Hillard, and W. D. Johnson, "Infra-red absorption spectra of metal chelates derived from 8-hydroxyquinoline, 2-methyl-8-hydroxyquinoline, and 4-methyl-8-hydroxyquinoline," Spectrochim Acta, vol. 8, p. 1, 1956.

[22] S. Panda, R. Mishra, A. K. Panda, and K. C. Satpathy, "Transition metal complexes with 4-amino-5-mercapto-3-methyl1,2,4-triazole and 8-hydroxyquinoline," Journal of the Indian Chemical Society, vol. 66, no. 7, pp. 472-474, 1989.

[23] P. V. Balkrishnan, S. K. Patil, H. D. Sharma, and H. V. Venkatsetly, "Chemistry of the complexes of uranyl and plutonyl ions with organic ligands," Canadian Journal of Chemistry, vol. 43, no. 7, pp. 2052-2058, 1965.

[24] K. M. M. S. Prakash, L. D. Prabhakar, and M. C. Chowdary, "Comeplexes of 1-(2'-hydroxybenzyl)-2-(2' -hydroxyphenyl)benzimidazole with U(VI) and Ce(IV)," Polyhedron, vol. 6, no. 2, pp. 285-288, 1987.

[25] C. C. Addison and W. B. Simpson, "Tin(iv) nitrate: the relation between structure and reactivity of metal nitrates," Journal of the Chemical Society (Resumed), pp. 598-602, 1965.

[26] P. S. Mansingh, R. R. Mohanty, S. Jena, and K. C. Dash, "Synthesis and characterization of dioxouranium(VI) and thorium(IV) complexes of 2-(2'-hydroxyphenyl)benzirnidazole and 2-(2'-pyridyl)-benzoxazole," Indian Journal of Chemistry A, vol. 35, no. 6, pp. 479-482, 1996.

[27] J. B. Gandhi and N. D. Kulkarni, "Synthesis, characteristics and redox properties of uranyl complexes with diamine ligands having ONNO and ONNNO donor groups," Indian Journal of Chemistry A, vol. 39, no. 4, pp. 461-464, 2000.

[28] K. Nakamoto, Infrared and Raman Spectra of Inorganic and Coordination Compounds, John Wiley and Sons, New York, NY, USA, 4th edition, 1986.

[29] W. M. Hosny, "Dioxouranium(Vi) mixed ligand complexes containing 8-hydroxyquinoline and some amino acids," Synthesis and Reactivity in Inorganic and Metal-Organic Chemistry, vol. 28, no. 6, pp. 1029-1052, 1998.

[30] R. V. Prasad and N. V. Thakkar, "Study of cobalt complexes as catalysts in the decomposition of hydrogen peroxide," Journal of Molecular Catalysis, vol. 92, no. 1, pp. 9-20, 1994.

[31] Z. H. Chohan, A. K. Misbahul, and M. Moazzam, "Synthesis, characterization and antimicrobial studies of $\mathrm{Co}(\mathrm{II})$ and $\mathrm{Ni}(\mathrm{II})$ complexes with some pyrazoles," Indian Journal of Chemistry A, vol. 27, p. 1102, 1988. 

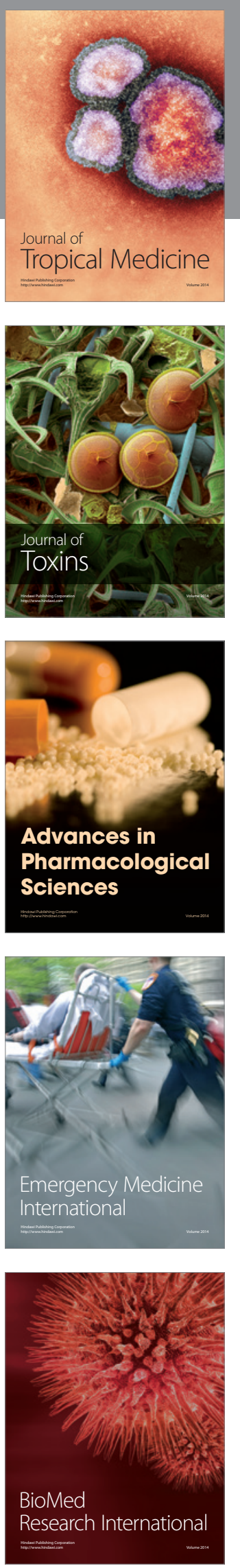
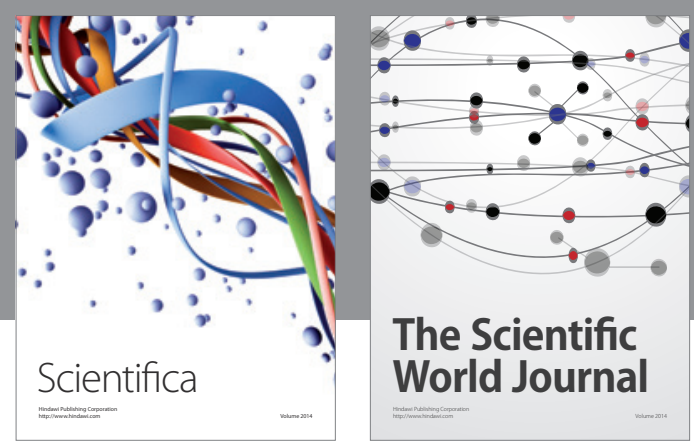

The Scientific World Journal
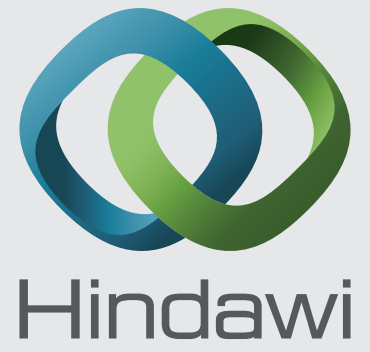

Submit your manuscripts at

http://www.hindawi.com
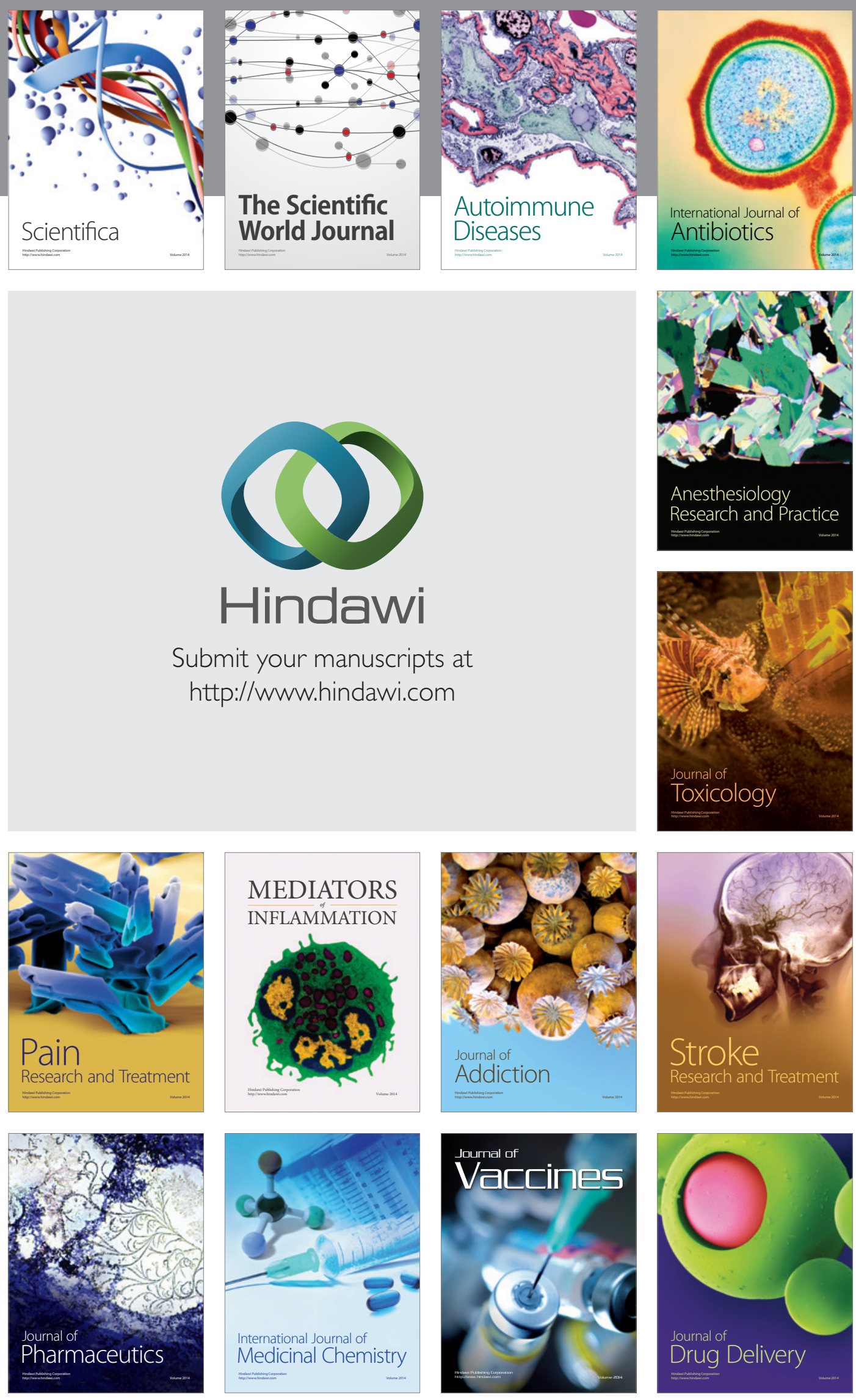